\title{
Rekomendasi Pemupukan Kalium pada Budi Daya Cabai Merah Besar (Capscicum annuum L) di Inceptisols Dramaga
}

\author{
Potassium Fertilization Recommendation for Red Chili Cultivation \\ (Capsicum annuum $L$ ) in Inceptisols Dramaga
}

Amanda Sari Widyanti ${ }^{1}$ dan Anas D. Susila ${ }^{1 *}$

Diterima 6 Mei 2015 / Disetujui 2 Juli 2015

\begin{abstract}
The objective of this study was to determine the optimum rate of potassium fertilization in Inceptisols Dramaga. The experiment was conducted at Cikabayan University Farm from March to July 2014. This study was arranged in Randomized Complete Block Design one factor with five $K$ fertilization rates, ie OX $\left(\mathrm{O} \mathrm{kg} \mathrm{K}_{2} \mathrm{O} \mathrm{ha} \mathrm{a}^{-1}\right), 1 / 4 \mathrm{X}\left(193.09 \mathrm{~kg} \mathrm{~K}_{2} \mathrm{O} \mathrm{ha}{ }^{-1}\right), 1 / 2 \mathrm{X}\left(386.19 \mathrm{~kg} \mathrm{~K}_{2} \mathrm{O} \mathrm{ha} \mathrm{f}^{-1}\right), 3 / 4 \mathrm{X}$ $\left(579.29 \mathrm{~kg} \mathrm{~K}_{2} \mathrm{O} \mathrm{ha} \mathrm{h}^{-1}\right)$, and $1 \mathrm{X}\left(772.39 \mathrm{~kg} \mathrm{~K} \mathrm{O} \mathrm{ha}^{-1}\right)$. Potassium fertilizer was applied in three applications at 3, 6, and 9 weeks after transplanting. The results showed that $K$ fertilization increased plant height, leaf number, weight per plant, fruit weight, fruit diameter, fruit length, marketable yield per plot, unmarketable yield per plot, marketable yield per hectare, and decrased unmarketable yield per hectare with linear response pattern. Addition of potassium did not affect the time of anthesis and fruit ripening. The addition of potassium fertilizer also increased total yield per plot and total yield per hectare with quadratic response pattern. In the medium $K$ soil content with the value of 146.2 ppm (Morgan) K recommendation for red chili in inceptisols Dramaga was 487.5 $\mathrm{kg} \mathrm{K}_{2} \mathrm{O} h \mathrm{~h}^{-1}$.
\end{abstract}

Keywords: fertilizer, $\mathrm{K}_{2} \mathrm{O}$, Morgan, optimum rate

\begin{abstract}
ABSTRAK
Penelitian ini bertujuan memperoleh dosis optimum pemupukan kalium pada Inceptisols Dramaga. Penelitian dilaksanakan di unit lapangan Cikabayan University Farm mulai Maret sampai Juli 2014. Penelitian ini menggunakan Rancangan Kelompok Lengkap Teracak (RKLT) 1 faktor dengan lima perlakuan dosis pemupukan $\mathrm{K}$, yaitu $0 \mathrm{X}\left(0 \mathrm{~kg} \mathrm{~K}_{2} \mathrm{O} \mathrm{ha}^{-1}\right), 1 / 4 \mathrm{X}\left(193.09 \mathrm{~kg} \mathrm{~K}_{2} \mathrm{O} \mathrm{ha}^{-1}\right), 1 / 2$ $\mathrm{X}\left(386.19 \mathrm{~kg} \mathrm{~K}_{2} \mathrm{O} \mathrm{ha}{ }^{-1}\right)$, $3 / 4 \mathrm{X}\left(579.29 \mathrm{~kg} \mathrm{~K}_{2} \mathrm{O} \mathrm{ha}{ }^{-1}\right)$, dan $1 \mathrm{X}\left(772.39 \mathrm{~kg} \mathrm{~K}_{2} \mathrm{O} \mathrm{ha}^{-1}\right)$. Pupuk kalium diaplikasikan dalam tiga kali aplikasi pada 3, 6, dan 9 MST. Hasil penelitian menunjukkan bahwa pemupukan $\mathrm{K}$ meningkatkan tinggi tanaman, jumlah daun, bobot tanaman ${ }^{-1}$, bobot per buah, diameter buah, panjang buah, bobot layak per petak, bobot tidak layak per petak, bobot layak per hektar, dan mengurangi bobot tidak layak pasar per hektar dengan pola respon linear. Sementara itu penambahan kalium tidak berpengaruh terhadap waktu antesis dan waktu masak buah. Penambahan pupuk kalium juga meningkatkan hasil bobot panen total per petak dan panen total per hektar dengan pola respon kuadratik. Pada tingkat kelas ketersediaan K sedang dengan nilai terekstrak 146.2 ppm (Morgan) dihasilkan rekomendasi kalium untuk budi daya cabai merah besar di inceptisols Dramaga adalah $487.5 \mathrm{~kg} \mathrm{~K}_{2} \mathrm{O} \mathrm{ha}^{-1}$.
\end{abstract}

Kata kunci: dosis optimum, $\mathrm{K}_{2} \mathrm{O}$, Morgan, pupuk

\section{PENDAHULUAN}

Cabai (Capsicum annuum L.) merupakan tanaman hortikultura penting dan salah satu komoditas strategis dengan nilai ekonomi tinggi di Indonesia (Kementan, 2012). Selama tahun 2013 produksi nasional cabai mencapai 1726382 ton (BPS, 2014). Produksi tersebut

${ }^{1}$ Departemen Agronomi dan Hortikultura, Fakultas Pertanian, Institut Pertanian Bogor

(Bogor Agricultural University), Jl. Meranti, Kampus IPB Darmaga, Bogor 16680, Indonesia

Telp.\&Faks.62-251-8629353.*Email korespondensi: anasdsusila10@ gmail.com 
melebihi target produksi cabai pada 2013 sebesar 1.47 juta ton. Produksi cabai merah selama periode 2008-2012 cenderung meningkat, namun pada saat ini produktivitas masih dikatakan rendah $0.20-0.33 \mathrm{~kg}$ pohon $^{-1}$ atau 6.84 ton $^{-1}{ }^{-1}$ (BPPN, 2013). Berdasarkan data tersebut, maka peningkatan produksi tanaman cabai masih perlu diupayakan. Tingkat keberhasilan tanaman untuk berproduksi secara maksimum tidak terlepas dari pengelolaan yang diberikan seperti teknik budi daya dengan mengaplikasikan pupuk sesuai kebutuhan tanaman dan lingkungan sekitar.

Banyaknya variasi rekomendasi pemupukan mengakibatkan produksi cabai di Indonesia belum maksimal. Rekomendasi pemupukan yang bervariasi terjadi karena Indonesia belum ada data baku rekomendasi pemupukan untuk komoditas cabai yang dibuat berdasarkan hasil analisis hara tanah. Petani melakukan pemupukan hanya berdasarkan pengalaman dari kegiatan bertanam sebelumnya atau menggunakan rekomendasi pemupukan yang tertera di kemasan pupuk yang digunakan, sedangkan dosis rekomendasi yang ada pada kemasan belum tentu dibuat berdasarkan hasil analisis hara tanah. Sampai saat ini data dasar status hara $\mathrm{K}$ pada lahan budi daya sayuran belum tersedia (Hilman $e t$ al., 2008). Dosis anjuran untuk tanaman sebagian besar juga masih bersifat sangat umum, padahal kebutuhan pupuk berbeda untuk setiap jenis tanaman, tanah, dan lokasi maupun teknik budi daya yang digunakan, sehingga uji tanah dan lokasi harus dilakukan (Rochayati et al., 1999). Penelitian Sari dan Suketi (2013) pada pengaruh aplikasi $\mathrm{GA}_{3}$ dan pemupukan NPK terhadap keragaan tanaman cabai menunjukkan bahwa dosis pupuk terbaik yang dapat mendukung pertumbuhan dan kualitas tanaman cabai ialah dosis $1.5 \mathrm{~g}$ NPK per polibag.

Unsur Kalium (K) merupakan salah satu unsur hara makro yang penting bagi tanaman, karena unsur ini terlibat langsung dalam beberapa proses fisiologis, sehingga dosis pemberian unsur $\mathrm{K}$ berpengaruh terhadap hasil produksi tanaman. Amisnaipa et al. (2009) dalam penelitian pemupukan $\mathrm{K}$ pada tanah Inceptisols Dramaga juga menunjukkan bahwa pada kelas hara $\mathrm{K}$ sangat rendah sampai sedang memberikan pengaruh signifikan terhadap tinggi tanaman tomat, rataan jumlah, diameter, dan bobot buah panen.
Analisis kandungan hara tanah sangat berpengaruh terhadap rekomendasi hara yang akan diberikan. Berdasarkan penelitan yang dilakukan Amisnaipa et al. (2009) metode analisis uji hara $\mathrm{K}$ pada tanah Inceptisols Dramaga dengan Morgan pada tanaman tomat merupakan metode pengekstrak yang memberikan nilai paling konsisten dengan kondisi hara dalam tanah. Kriteria nilai $\mathrm{K}$ terekstrak Morgan untuk menilai tingkat ketersediaan hara $\mathrm{K}$ adalah : (1) tergolong sangat rendah, jika nilai terekstraknya $<58.25 \mathrm{ppm} \mathrm{K}$, (2) rendah, jika nilai terekstraknya 58.25 - 103.25 ppm K, (3) sedang, jika nilai terekstraknya 103.25-205.00 ppm K, (4) tinggi dan sangat tinggi, jika nilai terekstraknya $\geq 205.00 \mathrm{ppm} \mathrm{K}$. Penelitian terhadap tomat tersebut menjadi dasar dilakukan penelitian ini sehingga akan dapat dihasilkan rekomendasi pemupukan $\mathrm{K}$ optimal untuk budi daya cabai merah besar di inceptisols Dramaga.

Penelitian penyusunan rekomendasi pemupukan berdasarkan uji tanah ini menindaklanjuti penelitian yang telah dilakukan oleh Amisnaipa et al. (2009) di lokasi yang sama namun komoditas berbeda. Penelitian yang dilakukan harus terencana, berkesinambungan, dan spesifik lokasi. Semakin sering penelitian dilakukan akan memperbaiki keakuratan rekomendasi dosis pupuk tersebut (Izhar et al., 2012). Tujuan dilakukannya penelitian ini ialah mendapatkan dosis rekomendasi optimal pemupukan K untuk budi daya tanaman cabai di Inceptisols Dramaga.

\section{METODE PENELITIAN}

Penelitian dilaksanakan mulai Maret 2014 sampai Juli 2014. Penelitian merupakan percobaan lapangan yang dilakukan di Kebun Percobaan University Farm, IPB, Cikabayan, Darmaga, Bogor. Jenis tanah adalah Inceptisols Darmaga. Analisis tanah dilakukan di Laboratorium Penelitian Kimia dan Uji Tanah, Balai Besar Sumber Daya Lahan Pertanian.

Bahan yang digunakan yaitu benih cabai merah besar varietas Gada F1. Bahan lain adalah pupuk urea $(46 \% \mathrm{~N})$, SP-36 (36\% $\left.\mathrm{P}_{2} \mathrm{O}_{5}\right)$ dan $\mathrm{KCl}\left(60 \% \mathrm{~K}_{2} \mathrm{O}\right)$, pupuk kandang, kapur Kalsium Karbonat $\left(\mathrm{CaCO}_{3}\right)$, media semai berupa arang sekam, pestisida jika diperlukan, dan bahan-bahan kimia untuk analisis tanah dan jaringan tanaman. Alat yang 
digunakan dalam pembuatan petak-petak percobaan serta penanaman adalah seperangkat alat budi daya pertanian berupa cangkul, sekop, ember, garu, tali tanam, dan sebagainya.

Penelitian ini menggunakan Rancangan Kelompok Teracak Lengkap (RKLT) satu faktor dengan lima taraf perlakuan yaitu $0 \mathrm{X}(0$ $\left.\mathrm{kg} \mathrm{K}_{2} \mathrm{O} \mathrm{ha} \mathrm{a}^{-1}\right), 1 / 4 \mathrm{X}\left(193.09 \mathrm{~kg} \mathrm{~K}_{2} \mathrm{O} \mathrm{ha}^{-1}, 1 / 2 \mathrm{X}\right.$ $\left(386.19 \mathrm{~kg} \mathrm{~K}_{2} \mathrm{O} \mathrm{ha}^{-1}\right), 3 / 4 \mathrm{X}\left(579.29 \mathrm{~kg} \mathrm{~K}_{2} \mathrm{O}\right.$ $\left.\mathrm{ha}^{-1}\right)$, dan $1 \mathrm{X}\left(772.39 \mathrm{~kg} \mathrm{~K}_{2} \mathrm{O} \mathrm{ha}{ }^{-1}\right)$ dimana $\mathrm{X}=777.39 \mathrm{~kg} \mathrm{~K}_{2} \mathrm{O}$ ha $^{-1}$. Nilai $\mathrm{X}$ didapatkan dari kurva erapan pada penelitian Amisnaipa et al. (2009). Setiap taraf perlakuan dilakukan empat ulangan, sehingga diperoleh 20 satuan percobaan. Pengaruh dari pemupukan kalium dapat diketahui dengan menggunakan uji $\mathrm{F}$ pada taraf kesalahan 5\%. Apabila terdapat pengaruh nyata terhadap peubah yang diamati maka dilanjutkan dengan uji Kontras Polynomial Orthogonal untuk mengetahui pola respon peubah terhadap perlakuan (Mattjik dan Sumertajaya, 2006).

Tahapan penelitian diawali dengan mengambil sampel tanah dari lokasi penelitian yang merupakan hamparan lahan seluas 150 $\mathrm{m}^{2}$. Sampel tanah diambil dari kedalaman 20 $\mathrm{cm}$ dari 10 titik pengambilan sampel. Analisis tanah dilakukan terhadap tekstur tanah, kadar C-organik, $\mathrm{N}$-total, $\mathrm{P}(\mathrm{HCl} 25 \%$ dan Bray 1), pH, KTK, KB, Al-dd, H-dd, Fe-bebas, unsur mikro tersedia ( $\mathrm{Fe}, \mathrm{Cu}, \mathrm{Zn}, \mathrm{Mn})$. Nilai $\mathrm{K}$ terekstrak tanah diperoleh dengan menganalisis kandungan $\mathrm{K}$ tanah menggunakan metode ekstraksi Morgan.

Ukuran petak percobaan adalah $5 \mathrm{~m} \mathrm{x}$ $1.5 \mathrm{~m}\left(7.5 \mathrm{~m}^{2}\right)$ sebanyak 20 petak dengan ukuran bedeng efektif $0.9 \mathrm{~m} \times 5 \mathrm{~m}$. Tinggi bedeng $0.3 \mathrm{~m}$, jarak antar bedeng $0.6 \mathrm{~m}$. Tanah yang digunakan merupakan Inseptisol Darmaga. Sementara dilakukan pengolahan tanah, benih cabai varietas Gada F1 disemai di tray menggunakan media tanam berupa arang sekam.

Dosis pemupukan $\mathrm{N}$ dan $\mathrm{P}$ berdasarkan rekomendasi Balitsa yaitu $151 \mathrm{~kg} \mathrm{~N}^{-1}$ dan $69 \mathrm{~kg} \mathrm{P}_{2} \mathrm{O}_{5} \mathrm{ha}^{-1}$ (Nurtika dan Hilman, 1995). Aplikasi pupuk kandang 20 ton ha ${ }^{-1}$ dan SP-36 $192 \mathrm{~kg} \mathrm{ha}^{-1}$ dilakukan dua minggu sebelum tanam. Dosis pemupukan $\mathrm{K}$ berdasarkan perlakuan. Pupuk susulan yaitu urea sebanyak $328 \mathrm{~kg} \mathrm{ha}^{-1}$ dan $\mathrm{KCl}$ diberikan 3 kali pada umur 3, 6, dan 9 minggu setelah tanam masingmasing $1 / 3$ dosis dengan cara disebarkan di sekitar lubang tanam kemudian ditutup dengan tanah.

Tahapan pemeliharaan yang dilakukan selama masa tumbuh tanaman cabai meliputi penyulaman, penyiraman, pemberantasan gulma dan pencegahan hama dan penyakit. Pemanenan pertama dilakukan pada 70 hari setelah tanam (HST) dan dilakukan pada pagi atau sore hari.

Tiap satuan percobaan diambil sepuluh tanaman contoh yang diambil secara acak untuk diamati. Pengamatan dilakukan dua minggu setelah pindah ke lapangan (transplanting) sampai dengan panen, dengan peubah pengamatan yaitu tinggi tanaman $(\mathrm{cm})$, jumlah daun (buah), waktu antesis (HST), umur buah masak (HST), diameter buah $(\mathrm{cm})$, panjang buah $(\mathrm{cm})$, bobot per buah $(\mathrm{g})$, bobot buah per tanaman $(\mathrm{g})$, bobot buah layak pasar $\left(\mathrm{g} \operatorname{tanaman}^{-1}\right)$, bobot buah tidak layak pasar (g tanaman $^{-1}$ ), dan bobot buah total $(\mathrm{g})$ per petak maupun per hektar.

\section{HASIL DAN PEMBAHASAN}

\section{Kondisi Umum}

Curah hujan pada saat penelitian antara 84.7-511 mm bulan ${ }^{-1}$ (BMKG, 2014). Curah hujan pada saat pindah tanam adalah $61.7 \mathrm{~mm}$ hari ${ }^{-1}$. Suhu di lapangan berkisar $25.8-26.5{ }^{0} \mathrm{C}$ dan kelembaban udara antara $83-85 \%$.

Cabai dipindah ke lapangan pada 28 hari setelah penyemaian dan dilakukan penyulaman pada 1 MST. Sebelum dipindah ke lapangan, lahan yang digunakan untuk penanaman cabai diambil contoh dari beberapa titik untuk dianalisis tingkat kesuburan tanah. Hasil analisis sifat fisik dan kimia tanah incepstisol Dramaga pada kebun percobaan Cikabayan dengan kedalaman 0-30 $\mathrm{cm}$ dapat dilihat pada Tabel 1.

Tanah Inceptisols yang digunakan bertekstur liat berdebu dengan kandungan pasir $7 \%$, debu $34 \%$, dan liat 59\%. Tanah bereaksi sangat masam karena memiliki $\mathrm{pH} 4.2$, sehingga $\mathrm{pH}$ tanah perlu ditingkatkan antara 5.5-6.8 agar dapat menunjang pertumbuhan cabai dengan baik. Peningkatan $\mathrm{pH}$ dilakukan dengan mengaplikasikan kapur pertanian sebanyak 2.6 ton $\mathrm{ha}^{-1}$. Penambahan bahan organik berupa pupuk kandang dengan dosis 20 ton ha ${ }^{-1}$ juga dilakukan karena kandungan bahan organik yang rendah dengan C-organik 1.59\%, N-organik 
$0.16 \%$, dan $\mathrm{C} / \mathrm{N}$ ratio 10 . Secara umum tingkat kesuburan tanah Inceptisols Dramaga di kebun percobaan Cikabayan tergolong rendah dengan pembatas utama kandungan $\mathrm{K}$ yang tergolong sedang (Tabel 2). Penambahan unsur-unsur hara melalui pemupukan sangat diperlukan untuk meningkatkan produksi cabai. Menurut Syafruddin et al. (2009) peningkatan kesuburan tanah dapat dilakukan dengan menerapkan aplikasi pupuk berimbang, yang artinya aplikasi pupuk dilakukan berdasarkan kebutuhan tanaman.

\section{Respon Tanaman pada Berbagai Penambahan Hara K Tanah Tinggi Tanaman}

Hasil analasis ragam menunjukkan bahwa penambahan $\mathrm{K}$ pada tanah Inceptisols
Dramaga dengan kondisi hara $\mathrm{K}$ sedang mempengaruhi pertumbuhan tinggi tanaman cabai secara signifikan mulai umur 4 sampai 8 MST (Tabel 3). Tinggi tanaman meningkat secara linier dengan penambahan $\mathrm{K}$ ke dalam tanah.

\section{Jumlah Daun}

Penambahan K ke dalam tanah juga memberi pengaruh signifikan terhadap jumlah daun mulai umur 5 sampai 8 MST (Tabel 4). Jumlah daun meningkat secara linear dengan penambahan $\mathrm{K}$ ke dalam tanah.

Tabel 1. Sifat fisik dan kimia tanah inceptisols Dramaga di lokasi kebun percobaan Cikabayan

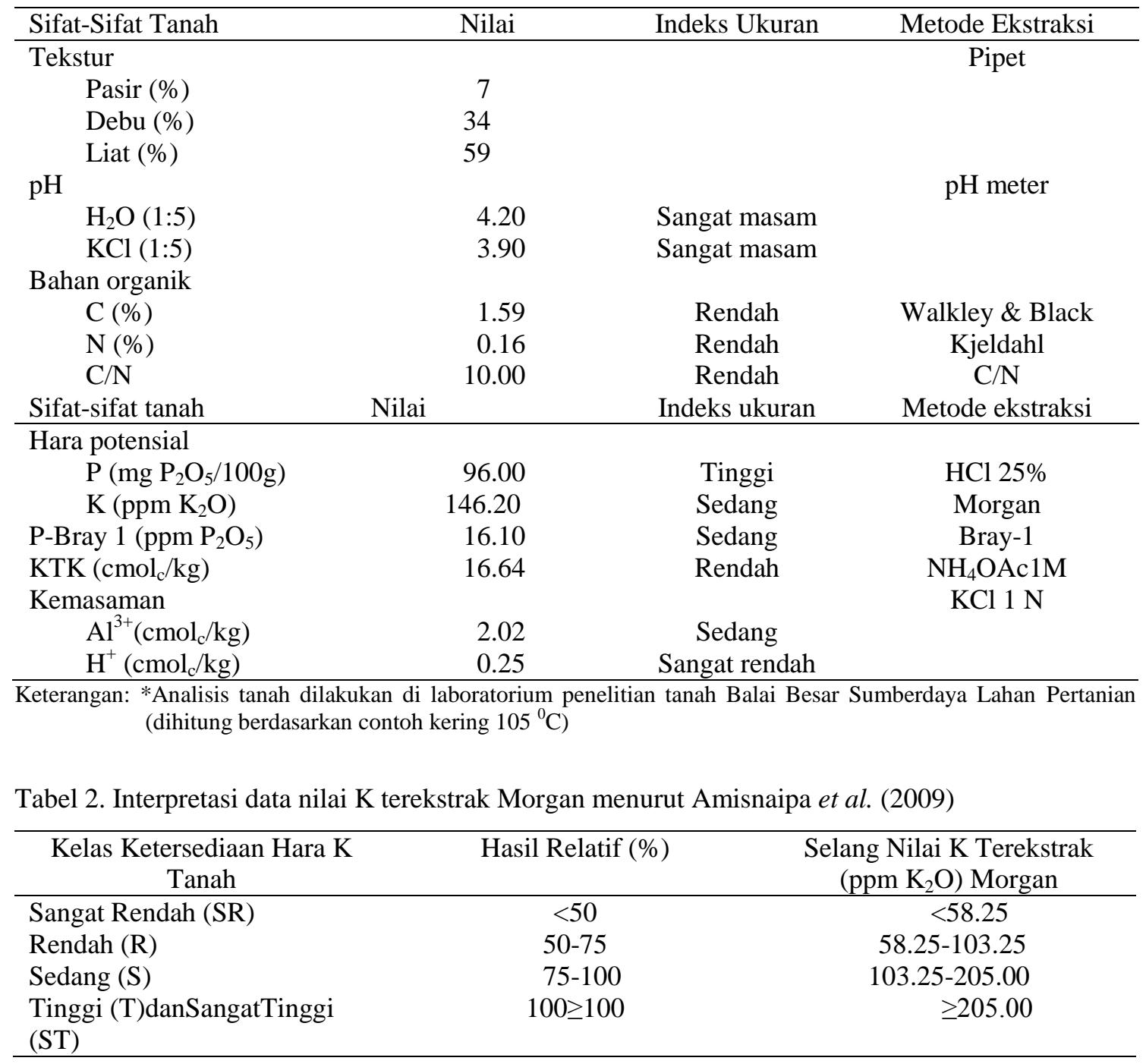




\section{Waktu Antesis dan Waktu Buah Masak}

Hasil analisis ragam menunjukkan bahwa penambahan $\mathrm{K}$ pada tanah tidak memberikan pengaruh terhadap waktu antesis dan waktu buah masak cabai (Tabel 5). Waktu antesis berkisar antara 24-25 hari setelah pindah tanam. Bunga cabai sudah banyak yang bermunculan pada 2-3 MST namun jumlahnya sangat sedikit dan banyak yang rontok. Waktu buah masak juga tidak dipengaruhi oleh penambahan K. Waktu buah masak berkisar antara 69-71 hari setelah pindah tanam.
Bobot Per Tanaman, Bobot Per Buah, Diameter Buah, dan Panjang Buah

Penambahan K ke dalam tanah memberi pengaruh signifikan pada bobot per tanaman, bobot per buah, diameter buah, dan panjang buah (Tabel 6). Bobot per tanaman meningkat secara linear dengan penambahan $\mathrm{K}$ ke dalam tanah. Diameter buah dan panjang buah juga dipengaruhi secara linear oleh penambahan $\mathrm{K}$ ke dalam tanah.

Tabel 3. Rataan tinggi tanaman $(\mathrm{cm})$ cabai pada berbagai penambahan $\mathrm{K}$ tanah

\begin{tabular}{lccccccc}
\hline $\begin{array}{l}\text { Penambahan K Tanah } \\
\left(\mathrm{kg} \mathrm{K}_{2} \mathrm{O} \mathrm{ha}^{-1}\right)\end{array}$ & 2 & 3 & 4 & 5 & 6 & 7 & 8 \\
\cline { 2 - 9 } & 21.51 & 25.31 & 38.88 & 40.99 & 44.30 & 48.78 & 51.77 \\
$0(0 \mathrm{X})$ & 21.60 & 25.52 & 40.59 & 46.41 & 50.85 & 55.41 & 58.36 \\
$193.09(1 / 4 \mathrm{X})$ & 21.23 & 25.98 & 41.58 & 50.26 & 54.52 & 59.67 & 62.83 \\
$386.19(1 / 2 \mathrm{X})$ & 21.33 & 25.79 & 43.92 & 52.85 & 56.75 & 61.35 & 65.05 \\
$579.29(3 / 4 \mathrm{X})$ & 21.83 & 26.27 & 44.06 & 56.42 & 60.92 & 65.02 & 68.58 \\
$772.39(\mathrm{X})$ & th & th & $*$ & $*$ & $*$ & $*$ & $*$ \\
\hline F test $^{\text {a }}$ & - & - & $\mathrm{L}^{* *}$ & $\mathrm{~L}^{* *}$ & $\mathrm{~L}^{* *}$ & $\mathrm{~L}^{* *}$ & $\mathrm{~L}^{* *}$ \\
Pola respon $^{\mathrm{b}}$ & & & & & & &
\end{tabular}

Keterangan: ${ }^{a}$ Uji $\mathrm{F}$ untuk melihat pengaruh penambahan $\mathrm{K}$ tanah terhadap tinggi tanaman; ${ }^{\mathrm{b}}$ Di uji dengan orthogonal polynomial; *= sangat nyata pada $\mathrm{P}<0.05 ; * *=$ sangat nyata pada $\mathrm{P}<0.01 ; \mathrm{tn}=$ tidak nyata; $\mathrm{L}=$ pola respon linear

Tabel 4. Rataan jumlah daun cabai pada berbagai penambahan K tanah

\begin{tabular}{lcrrrrrc}
\hline $\begin{array}{l}\text { Penambahan K Tanah } \\
\left(\mathrm{kg} \mathrm{K}_{2} \mathrm{O} \mathrm{ha}^{-1}\right)\end{array}$ & 2 & 3 & 4 & 5 & 6 & 7 & 8 \\
\cline { 2 - 8 } & 10.8 & 23.2 & 28.2 & 41.9 & 125.4 & 213.9 & 239.2 \\
$193.09(1 / 4 \mathrm{X})$ & 11.0 & 23.3 & 28.7 & 42.9 & 146.8 & 229.8 & 269.0 \\
$386.19(1 / 2 \mathrm{X})$ & 11.2 & 23.4 & 29.5 & 50.4 & 184.3 & 257.5 & 303.7 \\
$579.29(3 / 4 \mathrm{X})$ & 11.5 & 23.4 & 29.7 & 53.2 & 230.2 & 295.4 & 324.9 \\
$772.39(\mathrm{X})$ & 11.9 & 24.0 & 30.4 & 53.8 & 237.7 & 318.5 & 348.4 \\
\hline F test $^{\text {a }}$ & th & th & th & $*$ & $*$ & $*$ & $*$ \\
Pola respon $^{\text {b }}$ & - & - & - & $\mathrm{L}^{* *}$ & $\mathrm{~L}^{* *}$ & $\mathrm{~L}^{* *}$ & $\mathrm{~L}^{* *}$ \\
\hline
\end{tabular}

Keterangan: ${ }^{a}$ Uji $\mathrm{F}$ untuk melihat pengaruh penambahan $\mathrm{K}$ tanah terhadap jumlah daun; ${ }^{\mathrm{b}}$ Di uji dengan orthogonal polynomial; *= sangat nyata pada $\mathrm{P}<0.05 ; * *=$ sangat nyata pada $\mathrm{P}<0.01 ; \mathrm{tn}=$ tidak nyata; $\mathrm{L}=$ pola respon linear

Tabel 5. Rataan waktu antesis dan waktu buah masak pada berbagai penambahan $\mathrm{K}$ tanah

\begin{tabular}{lcc}
\hline $\begin{array}{l}\text { Penambahan K tanah } \\
\left(\mathrm{kg} \mathrm{K}_{2} \mathrm{O} \mathrm{ha}^{-1}\right)\end{array}$ & Waktu Antesis (hari) & Waktu Buah Masak (hari) \\
\hline $0(0 \mathrm{X})$ & 25.25 & 69.75 \\
$193.09(1 / 4 \mathrm{X})$ & 25.00 & 71.00 \\
$386.19(1 / 2 \mathrm{X})$ & 25.25 & 69.75 \\
$579.29(3 / 4 \mathrm{X})$ & 24.75 & 70.50 \\
$772.39(\mathrm{X})$ & 24.75 & 70.25 \\
\hline $\mathrm{F} \mathrm{test}^{\mathrm{a}}$ & tn & tn \\
Pola respon $^{\mathrm{b}}$ & - & - \\
\hline Keterangan: $^{\mathrm{a}} \mathrm{Uji}$ F untuk melihat pengaruh penambahan K tanah terhadap tinggi tanaman; ${ }^{\mathrm{b}}$ Di uji dengan orthogonal \\
\multicolumn{2}{c}{ polynomial; $^{*}=$ sangat nyata pada $\mathrm{P}<0.05 ; * *=$ sangat nyata pada $\mathrm{P}<0.01 ;$ tn $=$ tidak nyata }
\end{tabular}


Tabel 6. Rataan bobot per tanaman, bobot per buah, diameter buah, dan panjang buah cabai pada berbagai penambahan $\mathrm{K}$ tanah

\begin{tabular}{|c|c|c|c|c|}
\hline $\begin{array}{l}\text { Penambahan K tanah } \\
\left(\mathrm{kg} \mathrm{K}_{2} \mathrm{O} \mathrm{ha}^{-1}\right)\end{array}$ & $\begin{array}{l}\text { Bobot Tanaman }^{-1} \\
(\mathrm{~g})\end{array}$ & $\begin{array}{l}\text { Bobot } \text { Buah }^{-1} \\
(\mathrm{~g})\end{array}$ & $\begin{array}{l}\text { Diameter } \\
\text { Buah }(\mathrm{cm})\end{array}$ & $\begin{array}{c}\text { Panjang } \\
\text { Buah }(\mathrm{cm})\end{array}$ \\
\hline $0(0 X)$ & 345.30 & 9.01 & 1.02 & 10.76 \\
\hline $193.09(1 / 4 \mathrm{X})$ & 363.18 & 9.42 & 1.11 & 11.21 \\
\hline $386.19(1 / 2 X)$ & 384.54 & 10.37 & 1.12 & 11.97 \\
\hline $579.29(3 / 4 X)$ & 415.16 & 10.57 & 1.26 & 12.66 \\
\hline $772.39(\mathrm{X})$ & 429.39 & 10.41 & 1.27 & 12.66 \\
\hline F test ${ }^{a}$ & $*$ & $*$ & $*$ & $*$ \\
\hline Pola respon ${ }^{\mathrm{b}}$ & $\mathrm{L}^{* *}$ & $\mathrm{~L}^{* *}$ & $\mathrm{~L}^{* *}$ & $\mathrm{~L}^{* *}$ \\
\hline
\end{tabular}

Bobot Panen Layak (Marketable Yield) dan Tidak Layak (Unmarketable Yield)

Penambahan K pada tanah memberi pengaruh signifikan terhadap bobot panen layak dan tidak layak per petak serta per hektar. Perlakuan penambahan $\mathrm{K}_{2} \mathrm{O}$ sampai $772.39 \mathrm{~K}_{2} \mathrm{O}$ ha $^{-1}$ memberi pengaruh linear pada bobot layak dan tidak layak per petak dan per hektar (Tabel 7).

Tabel 7. Total bobot layak dan tidak layak per petak dan bobot layak dan tidak layak per hektar cabai pada berbagai penambahan $\mathrm{K}$ tanah

\begin{tabular}{|c|c|c|c|c|}
\hline \multirow{2}{*}{$\begin{array}{l}\text { Penambahan } \mathrm{K} \text { tanah } \\
\left(\mathrm{kg} \mathrm{K}_{2} \mathrm{O} \mathrm{ha}^{-1}\right)\end{array}$} & \multicolumn{2}{|c|}{$\operatorname{Bobot}^{P}{ }^{-1}{ }^{-1}(\mathrm{~g})$} & \multicolumn{2}{|c|}{ Bobot ha $^{-1}$ (ton) } \\
\hline & Layak & Tidak layak & Layak & Tidak layak \\
\hline $0(0 X)$ & 4636.25 & 1445.22 & 6.18 & 1.93 \\
\hline $193.09(1 / 4 \mathrm{X})$ & 4699.87 & 1402.25 & 6.26 & 1.87 \\
\hline $386.19(1 / 2 \mathrm{X})$ & 5256.17 & 1639.30 & 7.01 & 2.18 \\
\hline $579.29(3 / 4 \mathrm{X})$ & 5975.10 & 742.77 & 7.97 & 0.99 \\
\hline $772.39(\mathrm{X})$ & 6078.07 & 506.62 & 8.10 & 0.66 \\
\hline F test ${ }^{a}$ & $*$ & * & $*$ & $*$ \\
\hline Pola respon ${ }^{\mathrm{b}}$ & $\mathrm{L}^{* *}$ & $\mathrm{~L}^{* *}$ & $\mathrm{~L}^{* *}$ & $\mathrm{~L}^{* *}$ \\
\hline
\end{tabular}

Keterangan: ${ }^{a}$ Uji $\mathrm{F}$ untuk melihat pengaruh penambahan $\mathrm{K}$ tanah terhadap bobot panen total; ${ }^{\mathrm{b}}$ Di uji dengan orthogonal polynomial; $*$ sangat nyata pada $\mathrm{P}<0.05 ; * *=$ sangat nyata pada $\mathrm{P}<0.01 ; \mathrm{L}=$ linear

Tabel 8. Rataan bobot panen total per petak dan per hektar cabai pada berbagai penambahan $\mathrm{K}$ tanah

\begin{tabular}{|c|c|c|}
\hline $\begin{array}{l}\text { Penambahan K Tanah } \\
\left(\mathrm{kg} \mathrm{K}_{2} \mathrm{O} \mathrm{ha}^{-1}\right)\end{array}$ & $\begin{array}{c}\text { Bobot Total Petak }{ }^{-1} \\
(\mathrm{~g})\end{array}$ & $\begin{array}{l}\text { Bobot Total ha- } \\
\text { (ton) }\end{array}$ \\
\hline $0(0 X)$ & 6081.47 & 8.11 \\
\hline $193.09(1 / 4 \mathrm{X})$ & 6102.12 & 8.14 \\
\hline $386.19(1 / 2 \mathrm{X})$ & 6895.47 & 9.19 \\
\hline $579.29(3 / 4 X)$ & 6717.87 & 8.96 \\
\hline $772.39(\mathrm{X})$ & 6584.70 & 8.78 \\
\hline $\mathrm{F}$ test $^{\mathrm{a}}$ & $*$ & $*$ \\
\hline Pola respon ${ }^{b}$ & $\mathrm{Q}^{* *}$ & $\mathrm{Q}^{* *}$ \\
\hline
\end{tabular}




\section{Rekomendasi Pemupukan Kalium}

Berdasarkan uji tanah yang dilakukan menggunakan Morgan didapatkan bahwa kandungan $\mathrm{K}$ dalam tanah yang digunakan sebagai lahan penelitian adalah $146.2 \mathrm{ppm}$. Nilai tersebut tergolong sedang menurut interpretasi data pada penelitian Amisnaipa et al. (2009) yang dapat dilihat di Tabel 2 .

Kelas ketersediaan $\mathrm{K}$ sedang pada penelitian ini menghasilkan respon linear pada beberapa peubah yaitu, tinggi tanaman, jumlah daun, bobot buah per tanaman, bobot per buah, diameter buah, panjang buah, bobot buah layak dan tidak layak per petak serta bobot buah layak dan tidak layak per hektar. Peubah yang menghasilkan respon linear tidak dapat digunakan sebagai dasar rekomendasi pemupukan karena nilai dari parameter tersebut semakin meningkat dengan penambahan dosis aplikasi dan belum ditemukan titik optimalnya.

Rekomendasi pemupukan K untuk budi daya cabai pada tanah inceptisols Dramaga dapat disusun dari hasil panen total per bedeng maupun per hektar yang menghasilkan kurva kuadratik. Kurva kuadratik tersebut memiliki titik optimal yang dapat digunakan sebagai penyusun dosis rekomendasi pemupukan kalium pada kelas ketersediaan $\mathrm{K}$ sedang (Gambar 1).

Berdasarkan kurva respon hasil panen total per hektar cabai dapat dilihat bahwa telah ditemukan titik optimal pemberian dosis $\mathrm{K}_{2} \mathrm{O}$ $\mathrm{ha}^{-1}$. Respon bobot panen total baik per petak maupun per hektar menghasikan pola kuadratik yang dapat digunakan sebagai perhitungan dosis rekomendasi $\mathrm{K}_{2} \mathrm{O}$ pada kelas ketersediaan $\mathrm{K}$ sedang.

Rekomendasi pemupukan K untuk budi daya cabai pada tanah Inceptisols Dramaga pada kelas ketersediaan $\mathrm{K}$ sedang adalah 487.5 $\mathrm{kg} \mathrm{K}_{2} \mathrm{O}$ ha $^{-1}$ atau bila menggunakan pupuk $\mathrm{KCl}$ setara dengan $812.5 \mathrm{~kg} \mathrm{ha}^{-1}$. Dosis ini lebih besar dibandingkan dosis rekomen-dasi untuk tanaman tomat yang dilakukan oleh Amisnaipa et al. (2009) pada tanah Inceptisols Dramaga. Faktor-faktor yang dapat mempengaruhi kemungkinan adalah faktor lingkungan seperti cuaca yang kering. Curah hujan terendah pada saat penanaman di lahan adalah $84.7 \mathrm{~mm}$ bulan $^{-1}$ yang kemungkinan dapat mempengaruhi kebutuhan unsur $\mathrm{K}$ yang diserap tanaman. Hal tersebut karena kalium adalah unsur esensial yang dibutuhkan tanaman untuk meningkatkan produksi yang tinggi dan bisa menjadi faktor pembatas pada tanaman dalam keadaan lingkungan tertentu seperti kekeringan dan salinitas (Liebersbach et al., 2004).

\section{Pembahasan}

Pertumbuhan tanaman dan bobot panen berhubungan dengan ketersediaan $\mathrm{K}$ dalam tanah yang sesuai dengan penyataan Hassan et al. (1995) bahwa dengan meningkatkan pemupukan unsur $\mathrm{K}$ maka pertumbuhan tanaman dan bobot panen akan meningkat.

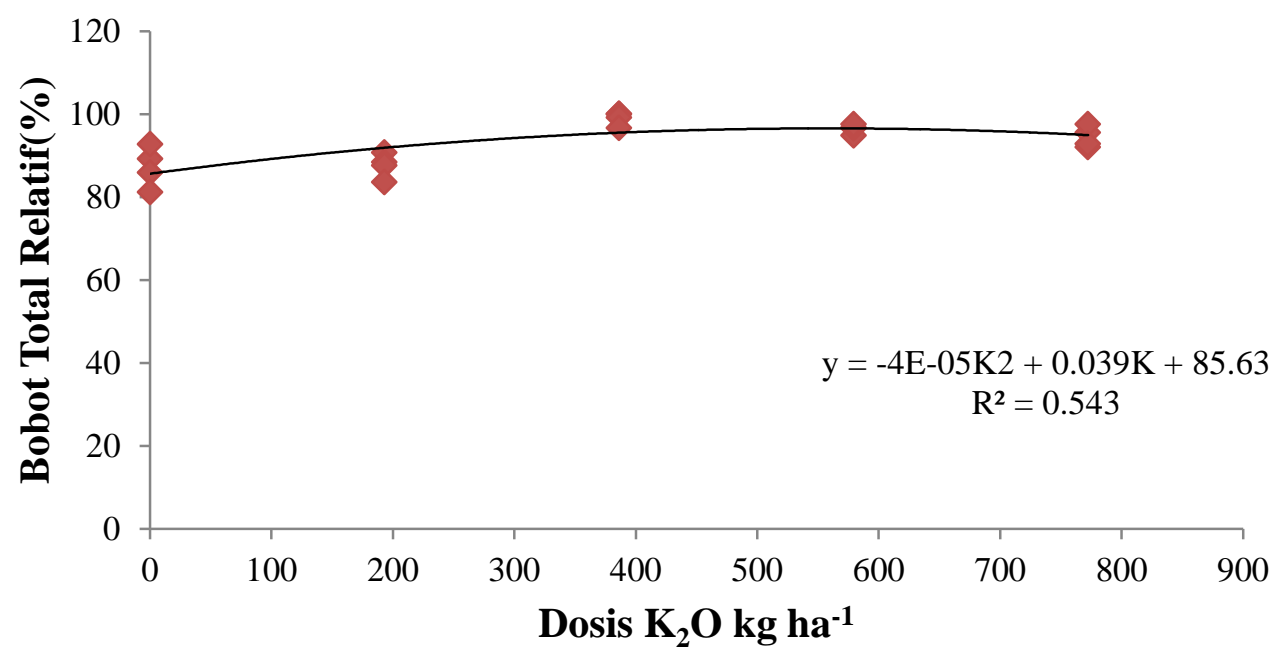

Gambar 1. Kurva respon hasil panen total per ha cabai terhadap pemupukan $\mathrm{K}$ 
Hal tersebut sesuai dengan peran utama kalium yaitu untuk aktivasi enzim yang terlibat dalam pembentukan struktur senyawa organik dan membangun senyawa seperti pati atau protein serta terlibat dalam pembelahan sel dan memicu pertumbuhan jaringan meristematik muda (Arquero et al., 2006). Jaringan meristem merupakan jaringan yang berpengaruh terhadap pertumbuhan tinggi tanaman dan akar.

Jumlah daun yang meningkat secara linear dengan penambahan dosis unsur $\mathrm{K}$ ini sesuai dengan penelitian El-Bassiony et al (2010) pada tanaman paprika yang menunjukkan bahwa tanaman tertinggi dan jumlah daun terbanyak pada paprika adalah dengan perlakuan $200 \mathrm{~kg} \mathrm{fed}^{-1}$ kalium sulfat, sementara jumlah daun terendah adalah pada tanaman yang hanya mendapat $50 \mathrm{~kg} \mathrm{fed}^{-1}$ kalium sulfat. Hasil ini dikarenakan fungsi kalium yang membantu proses metabolisme dan meningkatkan pertumbuhan vegetatif tanaman. Hal tersebut sesuai dengan pernyataan Wang et al. (2013) bahwa Kalium (K) adalah unsur penting pada proses biokimia dan fisiologis tanaman yang pada akhirnya mempengaruhi pertumbuhan dan metabolisme tanaman.

Ukuran buah juga meningkat dengan penambahan $\mathrm{K}$ hingga $772.39 \quad \mathrm{~K}_{2} \mathrm{O} \quad \mathrm{ha}^{-1}$. Ukuran buah dapat dilihat dari bobot per buah, panjang buah, dan diameter buah. Ketiga peubah tersebut berpengaruh signifikan secara linear dengan penambahan $\mathrm{K}$. Hal ini sesuai dengan hasil penelitian El Masry (2000) yang menyimpulkan bahwa kalium sangat berperan dalam peningkatan kualitas buah (Imas dan Bansal, 1999; Lester et al., 2006). Hasil ini juga sesuai dengan yang diperoleh pada penelitian sebelumnya oleh El Masry (2000), Ni-Wu et al. (2001) Ruchi-Sood dan Sharma (2004) dan Fawzy et al. (2007) pada tanaman terung dan Al Karaki (2000) dan Gupta dan Sengar (2000) pada tomat. Para peneliti ini menyimpulkan bahwa peningkatan kalium dalam tanah dapat digunakan untuk memperbaiki dan meningkatkan hasil tanaman serta kualitas buah. Menurut penelitian Golcz et al. (2012) pada tanaman paprika juga dilaporkan bahwa panen total, panen layak pasar, dan panen rata-rata per tanaman akan meningkat seiring dengan peningkatan aplikasi pupuk kalium.

Penambahan unsur $\mathrm{K}$ dalam bentuk pupuk $\mathrm{KCl}$ berpengaruh signifikan terhadap bobot panen layak, tidak layak, dan total.
Bobot panen layak pasar dan tidak layak pasar berpengaruh signifikan dengan kurva linear, sementara penambahan dosis $\mathrm{K}$ berpengaruh signifikan dengan kurva kuadratik pada bobot panen total per petak dan per hektar.

\section{KESIMPULAN}

Pemupukan $\mathrm{K}$ berpengaruh signifikan dengan pola linear terhadap tinggi tanaman mulai 4-8 MST, jumlah daun mulai 5-8 MST, bobot per tanaman, bobot per buah, diameter buah, panjang buah, bobot panen layak dan tidak layak per petak maupun per hektar. Sementara itu pada peubah waktu antesis dan umur buah masak pemupukan $\mathrm{K}$ tidak berpengaruh. Pada bobot panen total per petak dan per hektar pemupukan $\mathrm{K}$ berpengaruh sangat signifikan dengan pola kuadratik. Rekomendasi pemupukan $\mathrm{K}$ yang optimal untuk budi daya cabai di tanah Inceptisols Dramaga pada kelas ketersediaan $\mathrm{K}$ sedang adalah $487.5 \mathrm{~kg} \mathrm{~K}_{2} \mathrm{O}$ ha $^{-1}$ untuk mendapatkan hasil panen yang maksimal.

\section{DAFTAR PUSTAKA}

Al-Karaki, G.N. 2000. Growth, sodium, and potassium uptake and translocation in salt stressed tomato. J. Plant. Nutrition. 23(3): 369-379.

Amisnaipa, A.D. Susila, R. Situmorang, D.W. Purnomo. 2009. Penentuan kebutuhan pupuk kalium untuk budi daya tomat menggunakan irigasi tetes dan mulsa polyethilen. J. Agron. Indonesia. 37(2): 115-122.

Arquero, O., D. Barranco, M. Benlloch. 2006. Potassium starvation increases stomatal conductance in olive trees. Hort. Sci. 41(2): 433-436.

[BPPN] Badan Perencanaan Pembangunan Nasional. 2013. Rencana Pembangunan Jangka Menengah Nasional (RPJMN) Bidang Pangan dan Pertanian 20152019. Kementerian Perencanaan Pembangunan Nasional. Jakarta. 
[BPS] Badan Pusat Statistik. 2014. Data produksi sayuran Indonesia. http://bps. go.id. [ 28 Juli 2014].

El-Bassiony, A.M., Z.F. Fawzy, E.H. AbdSamad, G.S. Riad. 2010. Growth, yield, and fruit quality of sweet pepper plants (Capsicum annuum L) as affected by potassium fertilization. Journal of American Science. 6(12).

El-Masry, T.A. 2000. Growth, yield and fruit quality response in sweet pepper to varying rates of potassium fertilization and different concentrations of paclobutrazol foliar application. Annuals Agric. Sci. 28(2): 1147-1157.

Fawzy, Z.F., M.A. El-Nemr, S.A. Saleh. 2007. Influence of levels and methods of potassium fertilizer application on growth and yield of eggplant. J. Appl. Sci. Res. 3(1): 42-49.

Golzc, A., P. Kujawski, B. Markiewicz. 2012. Yielding of red pepper (Capsicum annuиm L) under the influence of varied potassium fertilization. J. Acta Scientiarum Polanorum-Hortorum Cultus. 11(4): 3-15.

Gupta, C.R., S.S. Sengar. 2000. Response of tomato (Lycopersicon esculentum Mill.) to nitrogen and potassium fertilization in acidic soil of Bastar. Veg Sci. 27(1): 9495.

Hassan, S.A., R.Z. Abidin, M.F. Ramlan. 1995. Growth and yield of chili (Capsicum annuum L) in response to mulching and potassium fertilization. Pertanika J. Trop. Agric. Sci. 18(2): 113-117.

Hilman, Y., H. Sutapradja, R. Rosliani, Y. Suryono. 2008. Status hara fosfat dan kalium di sentra sayuran dataran rendah. J. Hort. 18(1): 27-37.

Imas, P., S.K. Bansal. 1999. Potassium and integrated nutrient management in potato. Presented at the global conference on potato. Dec 6-11. New Delhi, India.
Izhar, L., A.D. Susila, B.S. Purwoko, A. Sutandi, I.W. Mangku. 2012. Penentuan metode terbaik uji fosfor untuk tanaman tomat pada tanah inceptisols. J. Hort. 22(2): 139-147.

Kementrian Pertanian. 2012. Pertanian Bioindustri Berkelanjutan: Solusi Pembangunan Indonesia Masa Depan. Biro Perencanaan Sekretariat Jendral Kementrian Pertanian. Jakarta.

Lester, G.E., J.L. Jifon, D.J.Makus. (2006). Supplemental foliar potassium applications with or without a surfactant can enhance netted muskmelon quality. Hort. Sci. 41(3): 741-744.

Liebersbach, H., B. Steingrobe, N. Claasen. 2004. Roots regulate ion transport in the rhizosphere to counteract reduced mobility in dry soil. Plant Soil. 260(12): $79-88$.

Mattjik, A.A., I.M. Sumertajaya. 2006. Perancangan Percobaan dengan Aplikasi SAS dan Minitab. Jilid I. IPB Press. Bogor.

Ni-Wu, X., S. Jian, R. Hardter. 2001. Yield and quality responses of selected solanaceous vegetable crops to potassium fertilization. Pedoshere. 11(3): 251-255.

Nurtika, N., Y. Hilman. 1995. Pengaruh sumber dosis pupuk kalium terhadap pertumbuhan dan hasil cabai yang ditumpangsarikan dengan bawang merah. Bul. Penel. Hort. 20(1): 131-136.

Rochayati, R., D. Setyorini, S. Suping, L.R. Widowati. 1999. Korelasi Uji Tanah Hara P dan K. [Laporan Tahunan] Bagian Proyek Penelitian Sumberdaya Lahan. Puslittanak. Bogor.

Ruchi, S., S.K. Sharma. 2004. Growth and yield of bell pepper (Capsicum annuиm var grossum) as influenced by micronutrient sprays. Indian J. Agric. Sci. 74(10): 557-559. 
Sari, Y., K. Suketi. 2013. Pengaruh aplikasi $\mathrm{GA}_{3}$ dan pemupukan NPK terhadap keragaan tanaman cabai sebagai tanaman hias pot. J. Hort. Indonesia 4(3) : $157-166$

Syafruddin, M. Rauf, R.Y. Arvan, M. Akil. 2009. Requirements for N, P, \& K fertilizers on Inceptisols Haplustepts soil. Indonesian Journal of Agriculture. 2(1): $77-84$.

Wang, M., Q. Zheng, Q. Shen, S. Guo. 2013. The critical role of potassium in plant stress response. Int. J. Mol. Sci. 14: 7370-7390. 